\title{
Energy Field Trips: Chernobyl and the Catastrophe with Nuclear Power
}

\section{JOHN H. PERKINS', NATALIE KOPYTKO² AND KATHLEEN M. SAUL ${ }^{3}$}

${ }^{1}$ Member of the Faculty Emeritus, The Evergreen State College, Olympia, WA 98505, USA, University of York, York, UK YO10 5DD, ${ }^{3}$ Member of the Faculty, Graduate Program on the Environment, The Evergreen State College, Olympia, WA 98505, USA Email: perkinsj@evergreen.edu

ABSTRACT Energy poses challenges to environmental studies because of climate change and other effects, and field trips are indispensable aids to learning. They enable students to see situations first-hand, and many are joyous and fun, such as field trips to forests, wetlands, wildlife reserves, or communities exhibiting positive contributions to safeguarding the natural world. Field trips to the built environment, especially those illustrating sites with raging controversies or past catastrophes are equally important in helping students turn theory into understanding of real situations. Chernobyl, one of the two worst nuclear power plant disasters, provided the venue for a field trip examining the strengths and weaknesses of nuclear power. Students had 3 weeks of preparatory classwork before departing for Kyiv, Ukraine. They spent 2 weeks there, with 1 day touring the Exclusion Zone surrounding the Chernobyl plant. Background work included basic concepts and units for measuring radiation and their biological and medical effects, types of nuclear power plants, disaster planning and response, Ukrainian history, and details of the Chernobyl accident and its effects. Participants heard from a wide variety of speakers, who presented details of the accident, its lingering consequences, efforts of the Ukrainian government and various NGOs to deal with the consequences, and Ukrainian plans for new nuclear power plants. Participants also heard both strong pro-nuclear and anti-nuclear proponents. At the end, students prepared a paper on the lessons about nuclear power from Chernobyl. Evaluations of the experience indicated the trip's objectives were achieved. For some, the expedition proved life-altering.

\section{A NOTE ON SPELLING OF UKRAINIAN AND RUSSIAN WORDS}

"Chernobyl" is the most common English spelling of the nuclear reactor that exploded in I 986, and it is the Russian word transliterated from Cyrillic to the Roman alphabet. "Chornobyl" is the word in Ukrainian, transliterated from Cyrillic to the Roman alphabet. Chornobyl is also a village, which supplied the name for the reactor complex. In most cases, we have used "Chernobyl", because it has become the standard and widely recognized word in English. "Chornobyl" appears when Ukrainians intended to use Ukrainian instead of Russian in the original.

The capital of Ukraine is Kyiv from Ukrainian and Kiev from Russian. We have used Kyiv in this essay.

\section{INTRODUCTION}

Field Trip

A visit made to a location outside one's typical domain for purposes of firsthand observation. For many, the mention of a field trip conjures up memories of bus rides to museums [I], parks, forests, wetlands, wildlife preserves, beaches, or caves - the natural environment [2].

Others have also argued, however, that field trips are a powerful teaching tool for exploring environmental issues in the built environment as well as the unbuilt [3]. In addition, outside of environmental studies, psychologists have emphasized the power of visiting sites where catastrophes occurred to bring home points of their discipline [4]. The field trip described here was to a place where a catastrophe occurred, Chernobyl, and it was an issue of the built environment.

Case Studies in the Environment, 2019, pps. I-13. electronic ISSN 2473-95 10. ( 2019 by the Regents of the University of California. All rights reserved. Please direct all requests for permission to photocopy or reproduce article content through the University of California Press's Reprints and Permissions web page, www.ucpress.edu/journals.php?p=reprints. DOI: https://doi.org/1 $0.1525 /$ cse.20 I 8.00 I 89 I 
Researchers agree that collaboration between teachers and field trip guides, a clear learning agenda, a degree of novelty in the field trip location, and direct links between classroom learning and field trip activities ensure field trip success. Whether for school children wishing to escape the strictures of the classroom, or for college students aiming to connect book-learning with the real world, field trips can offer a multi-dimensional, multi-sensory experience that builds critical thinking, enhances retention of material, and forges bonds between students, and students and teachers [5]. Field trips to sites in the built environment also provide opportunities for students to stimulate interest in subject matter, motivate informal learning, and challenge students' preconceived ideas and assumptions about the subject matter, thus powerfully boost the effectiveness of teaching and learning [6].

During the summer of 2007, a class at The Evergreen State College studied the catastrophic 1986 accident at Chernobyl and visited the site in Ukraine. This elective originated in the contexts of (a) an expected "nuclear renaissance," in which utilities would build many new nuclear power plants in the United States and (b) growing concern about the risks of climate change. The extended field trip to Ukraine served as a core aspect of the elective.

Anthropogenic climate change stems largely from the uses of fossil fuels. In addition, a myriad of health problems surrounds intensive extraction and uses of fossil fuels, especially coal. These detrimental effects also damage other species. Depletion of these fuels, particularly oil and gas, has stimulated drilling operations in difficult areas (offshore and the Arctic) and development of controversial technology (hydraulic fracturing or "fracking"), with continued risks of environmental damages. Intensive geopolitical tensions stem from heavy reliance on uranium and fossil fuels, especially oil, which together provide well over $80 \%$ of the world's energy [ 7 .

In 2007 , proponents of nuclear power and some scientists saw uranium as a fuel for generating electricity with much lower emissions of carbon dioxide compared to coal-fired power plants and thus a good way to mitigate climate change [8]. Critics of nuclear power at that time had concluded exactly the opposite, taking a life cycle view of emissions. Today, some climate scientists promote the necessity of nuclear power to mitigate climate change [9], and the justifications for environmental classes on energy remain even more compelling now than in 2007. Faculty and students in environmental studies need to understand energy issues, and field trips strongly increase the effectiveness of classroom work.

\section{BACKGROUND}

In $200 \mathrm{I}$, the new administration of President George W. Bush embraced a strong program of expanding energy supplies by every technology, including nuclear power. National Energy Policy: Reliable, Affordable, and Environmentally Sound Energy for America's Future [1 0$]$, often called the "Cheney Report," asked the Department of Energy (DOE) to address the potential for nuclear power to improve air quality and to ensure national security. Buoyed by this policy position, the nuclear industry foresaw a nuclear renaissance during which it would once again begin to build new nuclear power plants after a lapse of nearly 30 years [ I I ]. The subsequent Energy Policy Act of 2005 created the financial incentives to enable new construction [I 2]. Regulatory changes had streamlined the nuclear reactor permitting process. What was an appropriate response to these developments from environmental educators?

When environmental education had found its place in colleges and universities in the early I 970 , nuclear power was an important and controversial topic. At the time, the U.S. Atomic Energy Commission strongly promoted the transition of the U.S. electrical industry from fossil fuels to uranium [13]. Overly optimistic electricity forecasts and excessive economic costs brought the American nuclear industry to a halt by 1978 [1 4 ], but controversies about safety persisted throughout the i 970 (aggravated by the accident at Three Mile Island in 1979) and complicated debates [ I 5].

Congressional and Presidential support for nuclear power revived, however, and the Department of Energy convened a conference of scientists, engineers, and industry in 2004 to outline strategies for moving forward on constructing new reactors [16]. Thus, events within the United States had made it important for faculty in environmental studies to consider classes for exploring the strengths and weaknesses of nuclear power and competing energy sources.

Nuclear power's greatest strength lay uncontested: the technology can use heat from fission of uranium nuclei to produce prodigious amounts of electric power, generally welcomed by the public. In addition, proponents of nuclear power argued that, at least during reactor operations, electricity generation had minimal $\mathrm{CO}_{2}$ emissions 
and thus posed reduced hazards of climate change as compared to fossil fuels. Moreover, the supplies of nuclear fuels (uranium and possibly thorium) were enormous, claimed the proponents, and thus faced no depletion problems. In 2005 , solar wind, and geothermal heat each supplied $<0.5 \%$ of energy consumed, but uranium supplied $8 \%$, hydropower supplied $>3 \%$, and biomass supplied $3 \%$ [ 17 ]. Nuclear power had little competition from renewable energy sources, except for hydropower and biomass.

Despite lack of competition from renewable energy in 2007 , investments in nuclear power had proven so high and so financially risky during the I 970 s that only governments could build the plants, or they subsidized private building through loan guarantees, tax credits, and insurance against accidents. Subtler questions revolved around the best way to meet the demand for electrical energy, now and in the future. Issues of cost, appropriate sites, material degradation during operation of reactors, managing radioactive wastes, accidents, uranium supply, nuclear proliferation, depletion of material resources [ I 8], and the $\mathrm{CO}_{2}$ emissions of the total nuclear fuel cycle [19] all revealed serious weaknesses of nuclear power.

Consider safety of nuclear power plants. Accidents at Three Mile Island (Pennsylvania, I979) and Chernobyl (USSR, now Ukraine, 1986) generated significant public opposition to nuclear power in the United States. Economic problems had ground the American nuclear industry to a halt, but the safety issues loomed largest in the public's mind. These problems reappeared with renewed vigor after the Fukushima catastrophe in 20 I I.

\section{PLANNING THE COURSE AND FIELD} TRIP IN 2007

Framing of classes and field trips necessarily depends on thorough planning and on the background and interests of the faculty leading them [20]. Perkins was the lead faculty, and he emphasized the natural sciences (biology) and environmental and technological history. He selected safety and other scientific aspects surrounding nuclear power, in their historical contexts, as the major topics for the class. His objective was to have students understand the strengths and weaknesses of nuclear power as the appropriate policy remedy for energy and climate change: Should uranium and nuclear power retain or expand its role in powering the United States?
Perkins' interests converged with events and circumstances in Ukraine. Dissolution of the USSR in I99 I launched the newly independent republic of Ukraine, with the ruined Chernobyl nuclear power plant within its territory. To assist the newly independent, former Soviet republics build new futures, the U.S. government sponsored graduate students' studies in the United States. The Evergreen State College participated, and Tetyana Murza arrived for her master's degree in environmental studies in 2002. A Ukrainian, Murza had worked on nuclear power issues before coming to the United States. Under Perkins' supervision, she wrote her master's thesis on the issue of nuclear waste disposal in Ukraine. Murza returned to her native country in 2004, and in 2006 she coordinated the "Chornobyl +20" conference in Kyiv to commemorate the Chernobyl accident, and Perkins attended.

From this convergence of interests the field trip to Chernobyl and Kyiv emerged. Perkins had learned from Chornobyl +20 that the issues of safety of nuclear power appeared in strongest form in Ukraine at the site of the abandoned nuclear power plant. He consulted with Murza, and together they planned a summer class with the field trip for 2007 .

Murza and Perkins had already considered nuclear power a poor choice for generating electricity. They worked hard, however, to allow students to make up their own minds, even if that meant a strong embrace of nuclear power. They expected each student to ground their conclusions about nuclear power in knowledge gained (a) in the classroom and from observations in the field, (b) from speakers in Ukraine, (c) about different reactor types, (d) about the nature of radiation poisoning of human health and the environment, (e) about the comparisons of technical, economic, ecological, and social risks, and (f) about the need for electric power. Students' own experiences at the Chernobyl Nuclear Power Station and in the nearby town of Pripyat also would inform their ideas about the role of nuclear power in a climate constrained world. Thus, the work in the classroom directly tied to the agenda for the field trip [2 I ].

Advanced undergraduates and graduate students could enroll, and two undergraduates joined five graduate students, including Kopytko and Saul. In addition, two spouses participated in all activities, except the work required for academic credit (eight quarter hours for undergraduates and four for graduates). 


\section{THE ACADEMIC PROGRAM}

The class ran full-time for 5 weeks, the first three in Olympia, Washington, and the last two in Kyiv, Ukraine. Background work before departure included lectures and seminars about the basic concepts and units for measuring radiation, biological and medical effects of radiation, types of nuclear power plants, disaster planning and response, Ukrainian history, and details of the Chernobyl accident and its effects. Required student work included seminar papers and a mid-term exam.

Once in Ukraine, participants spent I day touring the Exclusion Zone surrounding the Chernobyl plant, learning firsthand about radiation levels, the scale of devastation, and life in the Zone. In Kyiv they heard a wide variety of government and NGO speakers, who presented the details of the accident, its lingering consequences, the efforts of the Ukrainian government and various NGOs to deal with the consequences, and the planning in Ukraine for additional nuclear power. Other guests to the program included strong pro- and anti-nuclear proponents. They heard from two physical scientists who had both been at the reactor site at the time of the accident; one remained committed to nuclear power and the other adamantly opposed it. Artists also shared their more nuanced interpretations of Chernobyl and its aftermath. The exhibits at the Ukrainian National Chernobyl Museum served as a visual reminder of the faces, the towns, and villages behind the statistics relating to the disaster.

The Exclusion Zone is about 2 hours by car north of Kyiv, about $100 \mathrm{~km}$, at the border with Belarus (Figure I). The national government strictly regulates travel in the Zone; arrangements to enter must be made in advance. People enter the Zone (total size about the same as Rhode Island) through passport control (Figure 2), where they meet their guide for the visit-for this tour a young member of the military. Visitors see the administrative building (Figure 3), with maps of radioactive contamination (Figure 4 ) in the Zone and surrounding areas.

The Chernobyl Nuclear Power Plant held four working reactors at the time of the catastrophe; Reactor Number 4 suffered explosions during a test of the reactor's emergency cooling system [22], and the destroyed reactor released radioactive debris that spread widely around the world [23]. Soviet engineers encased the ruins in a concrete "sarcophagus," viewed from a distance of about $100 \mathrm{~m}$. A Visitors' Center located near the ruined reactor has models showing what happened and a wide variety of pictures taken at the time of the accident and subsequently. A new shelter structure now surrounds the sarcophagus [24], but at the time of the 2007 visit, the nation relied on scaffolding to hold up portions of the crumbling sarcophagus (Figure 5).

The abandoned city of Pripyat (Figure 6) and abandoned villages (Figure 7) remain the most gripping part of the Zone. Pripyat arose from marshlands in the 1970 as a home for workers at Chernobyl Nuclear Power Plant. It had grown to about 50,000 people in 1986 . Hailed at the time as one of the most modern Soviet cities, it now sits as a ghost town, slowly crumbling to ruins. Other abandoned villages have traditional, rural Ukrainian houses, and they, too, are now mostly crumbling, at the mercy of plants, wild animals, and the weather. Our group visited Maria (Figure 8), who had returned to her village to live out her days, because it was home. She and one other person lived in a settlement formerly home to hundreds of people. They had no electricity and relied on a periodic visit from a delivery truck to supplement what food they raised themselves.

At the end of the field trip, students wrote essays from the point of view of an advisor to a political candidate for the President of the United States. The assignment presumed candidates wanted to know the implications of Chernobyl for the future of nuclear power in the United States. The overarching requirement was to incorporate their learning from the field trip into their arguments and to reach conclusions about the environmental advisability of embracing nuclear power as a source of electricity. As noted earlier, participants were encouraged to make up their own minds, even if it contradicted the assessments already reached by their instructors (which it sometimes did). This final exercise in critical thinking served as a "debrief" of the course and field trip [25].

\section{LOGISTICS AND COSTS}

Arranging the field trip required attention to the usual details associated with any off-campus venture. How would people travel, where would they sleep and eat, what would they see, with whom would they talk, and how much would it cost? The fact of travel in a foreign country, with a foreign currency and a foreign language, added some difficulties. In addition, the unique risks of the field trip had to be outlined to student participants. These challenges were eased by the fact that Murza was living in 


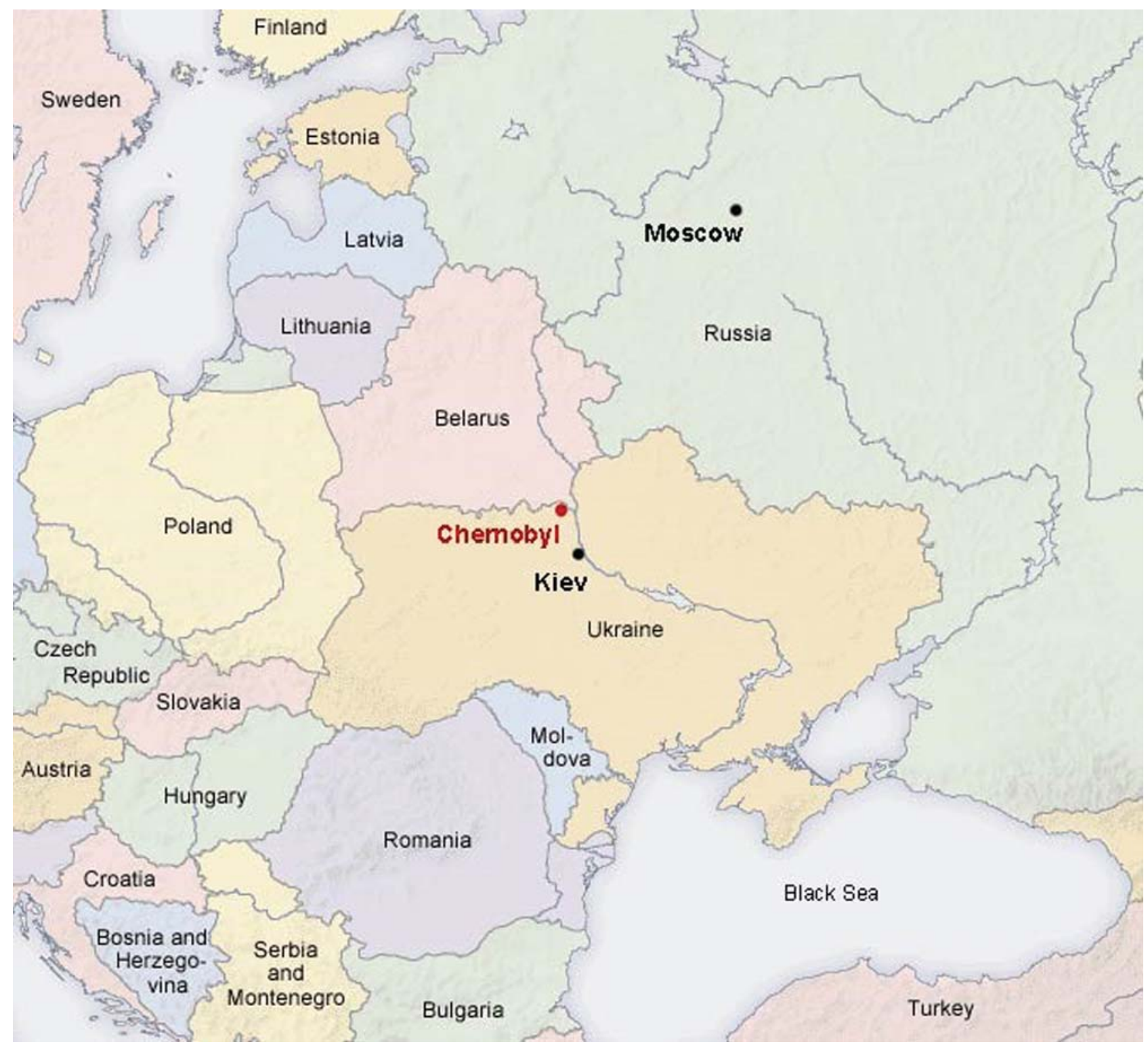

FIGURE 1. Map of Ukraine in Eastern Europe, showing location of Chernobyl site at the border with Belarus (map republished by GreenFacts, drawn from UN Chernobyl Forum, Chernobyl's Legacy: Health, Environmental, and Socio-Economic Impacts, 2006. Available: https://www.greenfacts.org/en/chernobyl/figtableboxes/map-chernobyl.htm), 26 November 2018.

Ukraine and spoke both Ukrainian and Russian as well as English. Perkins handled the arrangements with The Evergreen State College, and Murza made all arrangements in Ukraine. Murza also served as translator to English as needed.

The trip was expensive: US\$2,225, covered each student's airfare, lodging, travel expenses on required trips within and outside of Kyiv, and airfare and lodging expenses for the instructors. Participants themselves covered food in Kyiv and optional expenditures. Dining in cafeterias kept food costs down and allowed participants to point and choose food and beverages without a need for understanding Ukrainian, Russian, or the Cyrillic alphabet.

All participants traveled together to Ukraine, and almost all of them stayed at the same hotel in Kyiv. Participants did have the option of independent travel back to the United States. We ensured that all participants had upto-date passports, appropriate health insurance, and the latest health advisories.

No field trip leader can anticipate all the events that may befall participants, and this jaunt to Kyiv and Chernobyl was 


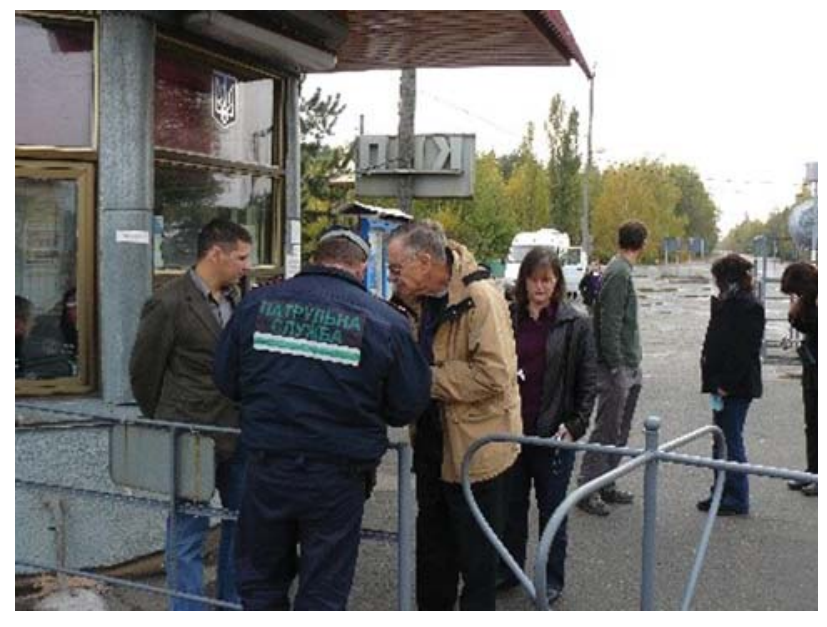

FIGURE 2. Passport control at the entrance of Chernobyl Exclusion Zone (photo by John Perkins, 2010).

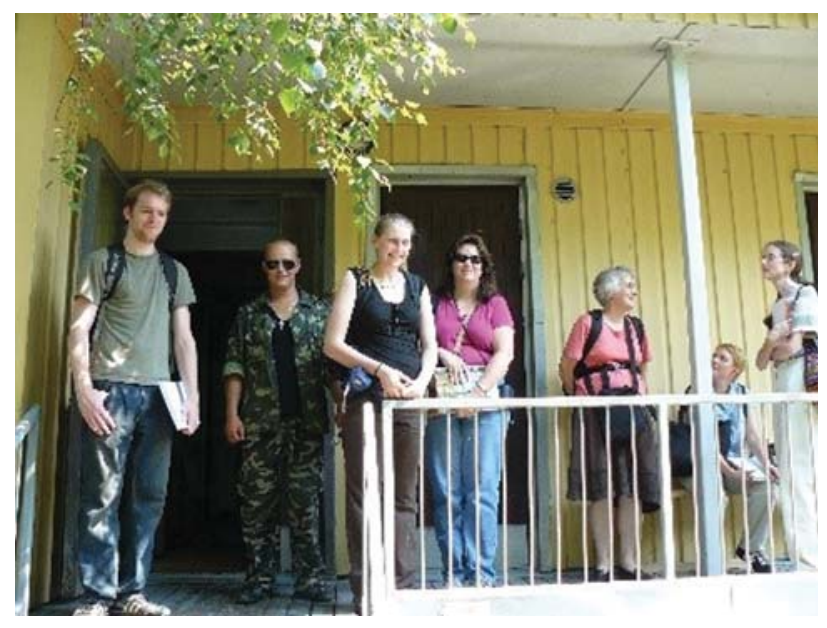

FIGURE 3. Administrative building within the Chernobyl Exclusion Zone, with participants and guide (photo by John Perkins, 2007).

no exception. Three contextual factors left an indelible impression on Perkins. First, the field trip was in July, i.e., summer time. We had anticipated warm weather, even for an area at about $50^{\circ}$ North latitude. And we knew Ukraine had a continental climate.

\section{RESULT}

It was hot! And humid! Many days were over $32{ }^{\circ} \mathrm{C}$ $\left(90^{\circ} \mathrm{F}\right)$, and a few reached $38^{\circ} \mathrm{C}\left(100^{\circ} \mathrm{F}\right)$. The original plan was for people to write their term research papers during the last few days of the expedition. That way, all work would be in, and students could relax and enjoy the trip home. Because of the stifling heat, absolutely no one

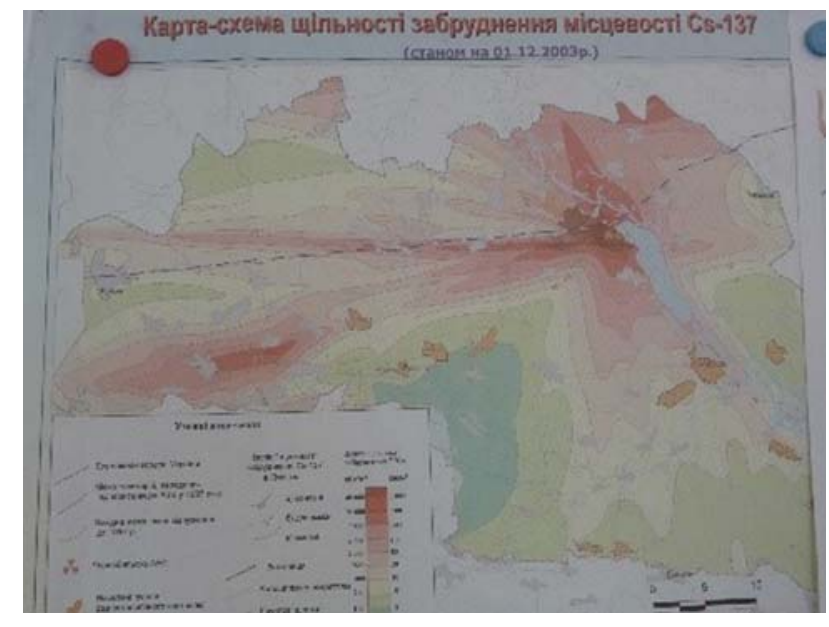

FIGURE 4. Map of Exclusion Zone showing contamination levels with Cesium-137 (photo by David McNelis, 2010).

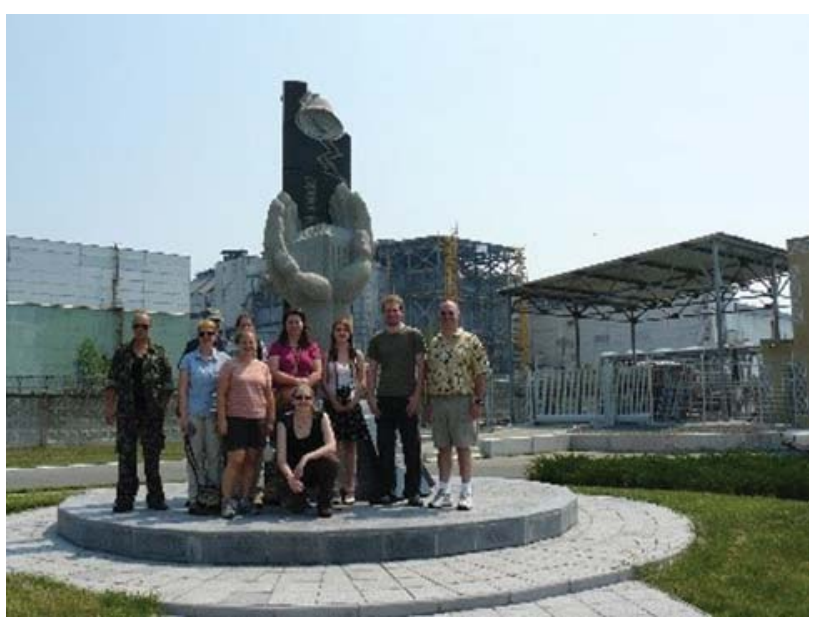

FIGURE 5. View of the sarcophagus surrounding the ruined Reactor Number 4 of the Chernobyl Nuclear Power Plant in Ukraine; scaffolding was installed to support the west wall; taken at monument to the catastrophe at the Visitor Center, 2007, with the participants (photo by Barbara Perkins).

had the energy to write a paper. Near the end, the faculty relented and announced students could finish the papers in Olympia. In addition, they truly needed time to process what they had seen and learned.

Second, parts of Kyiv, including the hotel housing most of the group, still relied on Soviet-era, centralized, hot water systems rather than independent water heaters. Once a year, the system is turned off for maintenance, and our stay in Kyiv overlapped completely with that time. Result? No hot water for showers in the hotel. Of course, with the hot weather a cold shower was not necessarily the worst thing in the world, but they were a shock. 


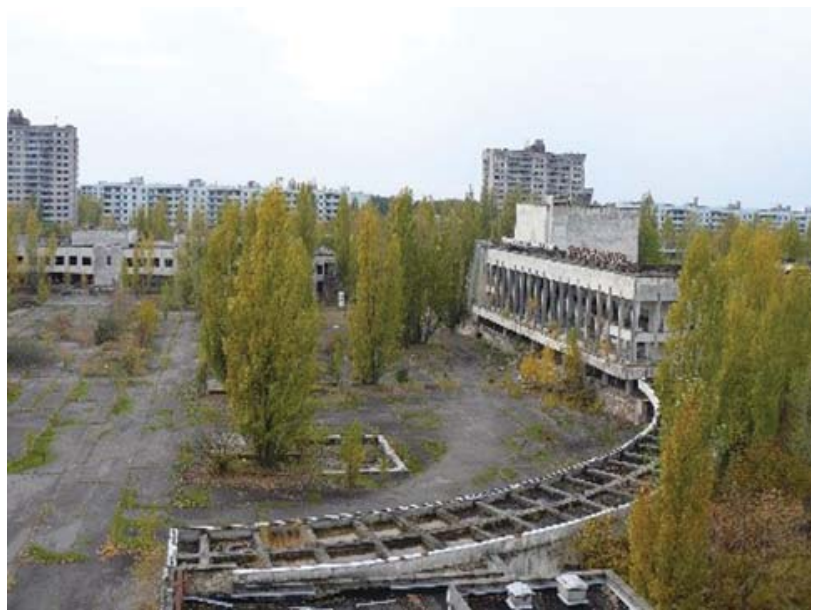

FIGURE 6. Central plaza in the abandoned city of Pripyat (photo by John Perkins, 2010).

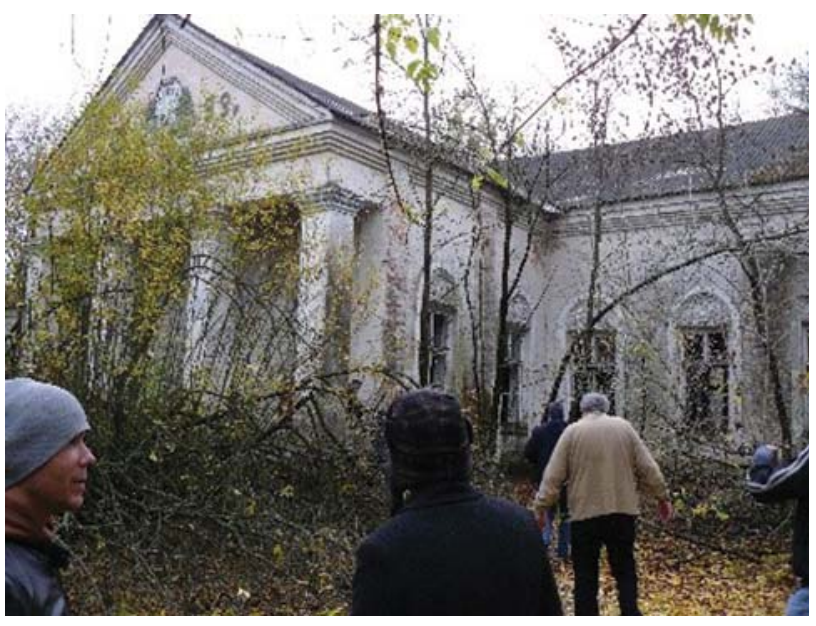

FIGURE 7. Village administrative building, abandoned, inside Chernobyl Exclusion Zone (photo by John Perkins, 2016).

Finally, the hotel was an older, Soviet hotel, not much refurbished for many years. Compared to hotels in the United States, it was a pretty good place, generally somewhere between I and 2 stars. It was clean, but certainly not fancy. What Perkins didn't realize, until after the group's return, was that one of the rooms had a colony of bats in residence. Even though they devoured pesky mosquitoes, this truly horrified him. (Perhaps, a bit too much novelty for the optimum field trip experience!)

Insufferable heat, no hot water, bats, and water dripping inside the van the group took to Chernobyl, but not a peep of complaint from the participants. They had the flexibility to roll with the punches and make the trip a joy!

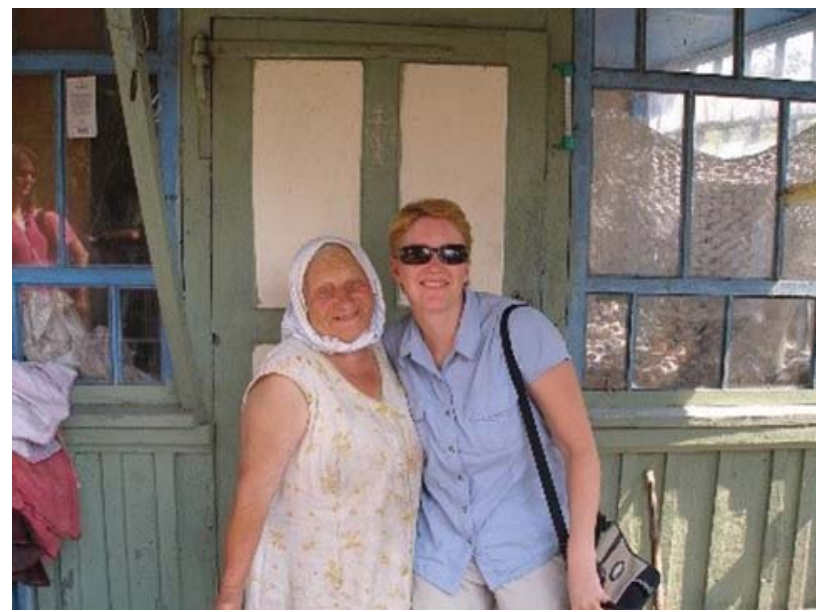

FIGURE 8. Maria and Natalie Kopytko at Maria's home in the Chernobyl Exclusion Zone (photo by an unknown participant in Evergreen's field trip to Chernobyl, 2007).

\section{EVALUATION OF THE FIELD TRIP AND REPETITIONS}

The behavior of all participants was exemplary, and the trip was instructive, moving, and fun. The course and field trip accomplished exactly its intended objective; the controversies and issues surrounding nuclear power came alive; and participants no longer saw nuclear power as an abstract issue covered in dusty books and papers. Nuclear power became a burning issue that continued to affect peoples' lives and destinies.

In terms of conclusions about nuclear power, one student was strongly pro-nuclear before and remained so afterward. She did, however, gain a radically new appreciation for the absolute necessity for strict safety standards and procedures. The other six students were either agnostic or somewhat opposed to nuclear power before the trip but moved toward greater skepticism or outright opposition due to their experiences. Differences of opinions did not seem to hinder the mutual respect and collaboration of all participants on the field trip.

The aim was to offer this summer course and a field trip to Ukraine each year, but for two reasons that did not happen. First, the expenses for the trip were high, very high. At the anticipated participation rate of I 5 students, the costs would have lowered a small amount. It would have been difficult to accommodate > I 5 , so expenses would always be a barrier. The financial collapse of 2008 may have sealed the fate of this venture. Efforts to offer it in 2008 and 2009 did not draw enough students with the financial means to participate (Perkins retired in 2009). 
Second, the enthusiasm for nuclear power significantly dissipated after 2009. The new President, Barack Obama, remained open to more nuclear power, and the financial incentives of the Energy Policy Act of 2005 remained in place. Still, with few exceptions, most utilities in the United States never regained interest in nuclear power. That interest has since soured in South Carolina [26] and remains contested in Georgia [27]. Tennessee Valley Authority completed Watts Bar Unit 2, started in I 973. It came online in 2016 , but it had to close for repairs only 5 months later [28].

Perkins received a grant in $20 \mathrm{I} 0$ from the Trust for Mutual Understanding to lead a study-trip of university and high school faculty to Chernobyl. He collaborated with Andriy Martynyuk, a former colleague of Murza's, on the trip. While the trip succeeded in allowing faculty members to gain experience about Chernobyl, terms of the grant did not permit participation by students.

\section{LASTING EFFECTS OF THE FIELD TRIP}

Two of the authors of this paper had transformative experiences during this course, due primarily to the field trip component. In line with other research on field trip experiences, these students found that the trip stimulated their interest in aspects of nuclear power, sharpened their perception and observation skills, and provided an invaluable first-hand experience with the aftermath of a nuclear catastrophe [29]. The following presents their individual reflections.

Natalie Kopytko: Response to Field Trip on Nuclear Power A desire to visit Ukraine and to answer a "burning" question about nuclear power attracted me to the course. I returned from the trip highly motivated to research nuclear power safety and accidents. A few months later, I changed my thesis topic from wetland research to nuclear power. The significance of that decision became fully evident after the Fukushima accident in $20 \mathrm{Ir}$. Finally, the skills and contacts gained from the field trip helped with the $\mathrm{PhD}$ research I would eventually carry out in Ukraine. My life would be very different had I not gone on this field trip.

I grew up in the Canadian prairies where the Ukrainian diaspora has been a significant part of our cultural melting pot for over 100 years. My Dad's parents were amongst the first wave of Ukrainian immigrants to Canada. They farmed and raised a family of fourteen.
This large Ukrainian family was a significant part of my life, so I could not pass up an opportunity to finally visit Ukraine. In an academic sense, I had an interest in climate change and was firmly positioned in the "I'm not sure/I'm not convinced" camp when it came to nuclear power. While some environmentalists were endorsing nuclear power at the time, I decided I did not know enough to make an informed decision.

Ultimately, I arrived at an informed decision by engaging with a wide range of perspectives pertaining to nuclear power provided by this course. Independent of the field trip, this course stands out as my favorite learning experience due to various background readings. The required readings included technical accounts, natural histories, ethnographies, and even a piece of fiction set in the exclusion zone. Once on the field trip, various speakers presenting from different perspectives aligned well with interdisciplinary reading materials.

For me, the most memorable speaker on the trip was the former head of safety at Chernobyl. It was fascinating to hear someone very knowledgeable from working in the field and previously in favor of nuclear power so strongly opposed to nuclear power. He spoke of a safety incident at a Florida nuclear power plant that could have had serious consequences. I was completely unaware of the incident, but, when I returned from Ukraine, learning about that incident provided a starting point for my research into nuclear safety in the United States. I wrote a paper comparing the similarities between nuclear accidents instead of considering each as anomalies or blaming accidents on "human error." Nuclear power is designed, built, and operated by humans. Therefore, human error will play a part in all accidents and does not provide any analytical insight.

From this experience, I became skilled at uncovering and understanding the cons of the very secretive nuclear industry. I decided to focus my thesis on how climate change impacts nuclear power. Nuclear power depends on cooling water and is vulnerable to heat waves, drought, and flooding. Safety incidents in the United States happened during hurricanes due to the multiple hazards associated with storm surges. Perkins and I published this work in Energy Policy [30], but that was not the last time I would write about climate and nuclear power. While no accidents ever happened during hurricanes, I had little confidence in this trend continuing. The reports I read mentioned safety doors being found open after hurricanes 
had passed and damaged safety devices. Any time I heard a hurricane was approaching a state with nuclear power plants; I held my breath a little as I followed the news closely. When I heard that a tsunami had hit a nuclear power plant in Japan, I was continuously searching for updates. From the media coverage, it quickly became evident that the cause and thus any future safety concerns would be limited to nuclear power plants near fault lines. I knew I had to speak up. Again, I thought about that one very memorable speaker from the field trip telling us that he wanted us to speak up against nuclear power. It was his one request from us after he had shared so much knowledge. I emailed The Guardian explaining the Energy Policy publication. They saw that it was a new angle, so they asked me to write for the comment section [3 I]. From there I had requests from New Scientist [32] and The Bulletin of the Atomic Scientists [33], interviews with journalists from other newspapers in Europe, and a call from a representative in the European Parliament. None of this would have happened if I had not made that field trip to Ukraine.

Although I am not currently researching nuclear power, my $\mathrm{PhD}$ research benefited from the experience of that field trip. I wanted to research an area where climate change presents opportunities and not just challenges, so I decided to research climate and agriculture. I moved to the UK and to my surprise my supervisor was interested in conducting research in Eastern Europe. I seized the opportunity to conduct research in Ukraine. Murza and Perkins organized such a wonderfully diverse and giving group of speakers for the field trip. I think that positive experience made me see the possibilities of building research networks in another country. Thanks to the Evergreen field trip I had at least a few connections that I could use to build my own network in Ukraine. After several research trips to Ukraine, I received my PhD in 2017.

Moreover, as a lecturer, I now tell a new group of students about my experience visiting and learning about the exclusion zone. The novelty of the location attracts immediate attention and surprise from students. Recently, I included Pripyat as a case in a lecture about shrinking cities. Students appeared surprised to learn about the construction of a solar farm on site and even more surprised to learn that people still live there. I relay to them the direct experience of seeing radiation measurements at different locations to explain that the farmland belonging to the resident we visited (Maria) appeared to have lower radiation than many other sites. Seeing "spotty" radiation levels on a map is one thing, but seeing it in real life creates an indelible memory.

I made that field trip to Ukraine over so years ago, and it has continued to have consequences in my academic and personal life. I have learned a great deal, but as importantly, after several research trips to Ukraine, I have also built important and lasting friendships. The experience at the time of the trip was incredible, but I can also say it changed my life.

Kathleen Saul: Response to the Field Trip on Nuclear Power I only had dim memories of the actual accident at Chernobyl: worrying about the fate of my favorite Soviet gymnast, Olga Korbut, and friends in Romania. During an earlier foray into graduate school, I studied with an Australian professor at Wharton who worried about living so close to the infamous Three Mile Island nuclear site in Pennsylvania. Thus, having a chance to learn more about nuclear power and then to travel Ukraine and Chernobyl intrigued me. I signed up for Chernobyl and Ukraine.

I anticipated an intellectual journey; I did not expect the trip to have such an emotional impact on me.

The Exclusion Zone-the foci of any trip into the Chernobyl Exclusion Zone are a glimpse at the stricken reactor, now shrouded in scaffolding, and a visit to Pripyat, home to Chernobyl workers and their families. The huge concrete edifices and even bigger cranes still hovering over unfinished structures at the two sites bore witness to the enormity of the project underway at the time of the catastrophe. The emptiness and the lack of any sounds or signs of human life, even at the children's playground (Figure 9), evoked a sense lives interrupted, futures forever altered. Even the moss that dared to invade the sidewalks remained highly radioactive (Figure $\mathrm{o})$. However, for the most part, the death, fear, loss, and uncertainty of those days in 1986 lie hidden behind a surface that seems calm and safe.

Ukrainian National Chernobyl Museum, Kievdescribed as a history museum in the literature, this out of the way building turned out to be more of an artistic expression of the event, a passionate response to it, than a purely historic gallery. Road signs for villages abandoned that fateful day decorate the stairwells (Figure I I), eerily vacant hazardous materials suits stand like ghosts (Figure I 2), lifeless black and white photos of people who toiled selflessly to put out the fire and cap the structure 


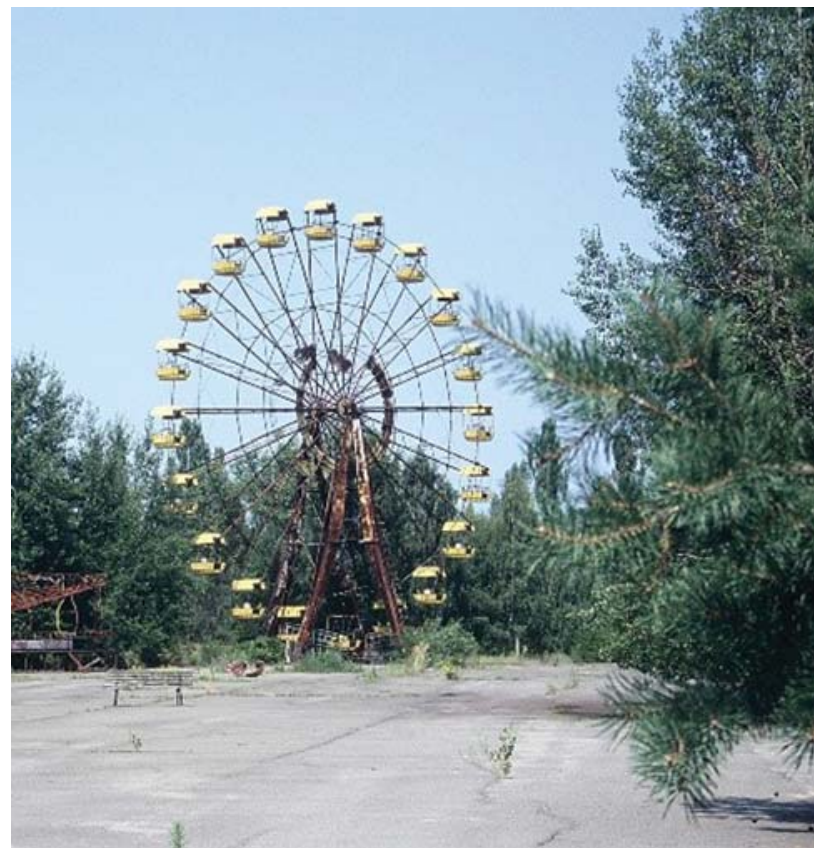

FIGURE 9. Ferris wheel at an abandoned amusement park, Pripyat (photo by Kathleen Saul, 2007).

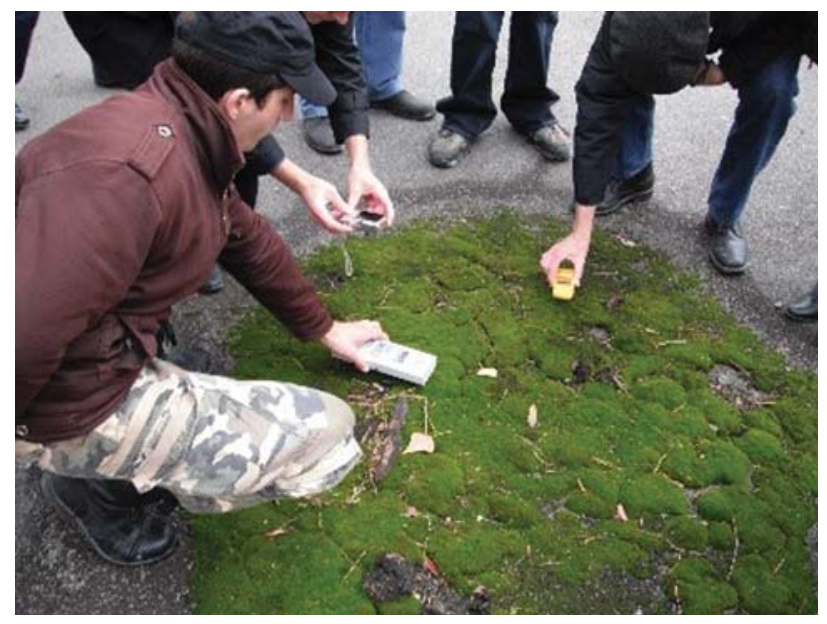

FIgURE 10. Moss in Pripyat showing comparatively high levels of radiation compared to surrounding area (photo by Cathy Middlecamp, 2010).

stare out from one wall, photos of children affected by the disaster watch from another (Figure I 3). I left feeling heartbroken, drained, and questioned the value of a technology that could have such a profound impact.

Discussions with scientists, physicians, and people working on behalf of children affected by radiation incited frustration and a degree of anger. The results of years of experimental and observational work about

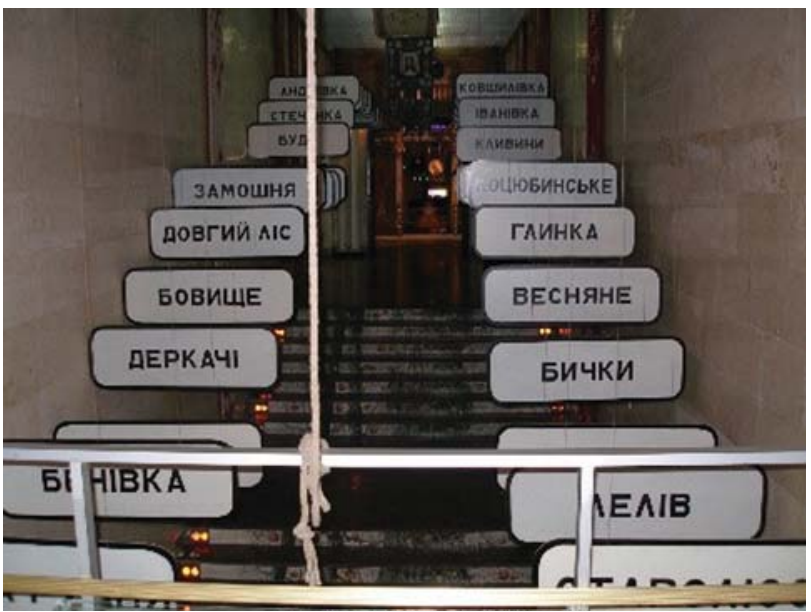

FIGURE 11. Chernobyl Museum, Kyiv, showing signs of abandoned villages located in the Chernobyl Exclusion Zone (photo by Natalie Kopytko, 2007).

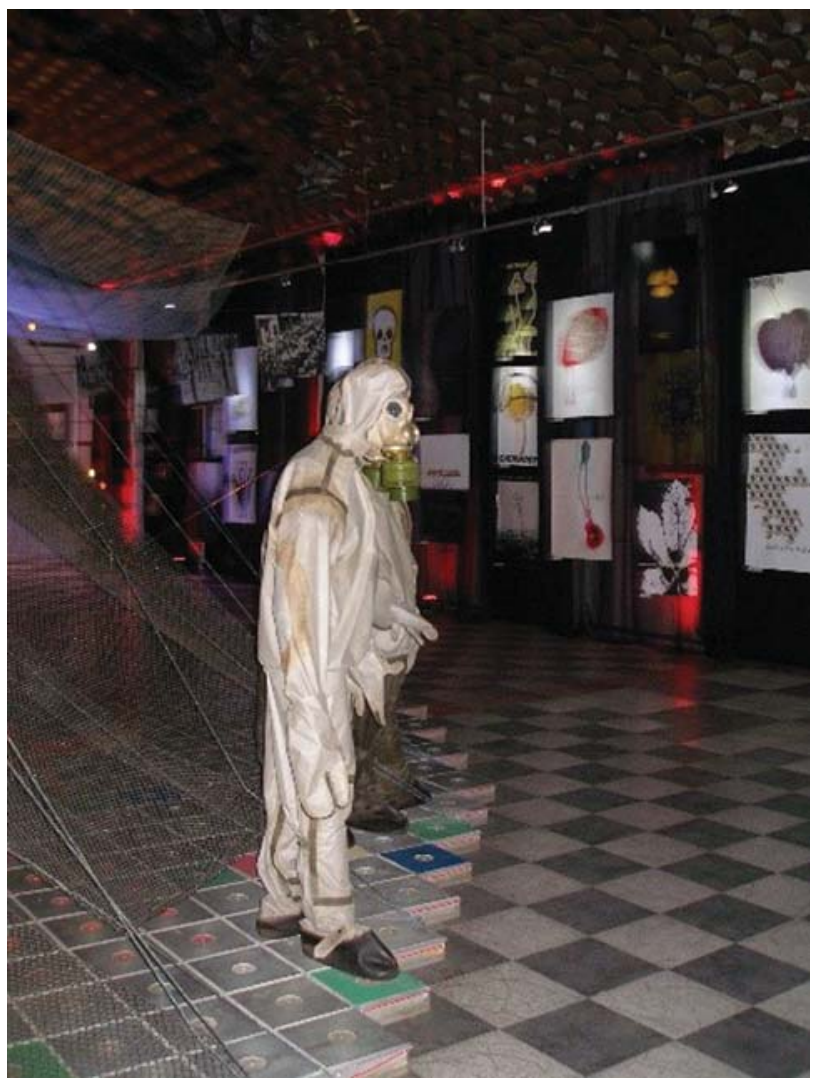

FIGURE 12. Chernobyl Museum, Kyiv, showing hazardous materials suits from the Chernobyl catastrophe (but such suits were not available to protect the first responders, many of whom died of acute radiation sickness) (photo by Natalie Kopytko, 2007). 


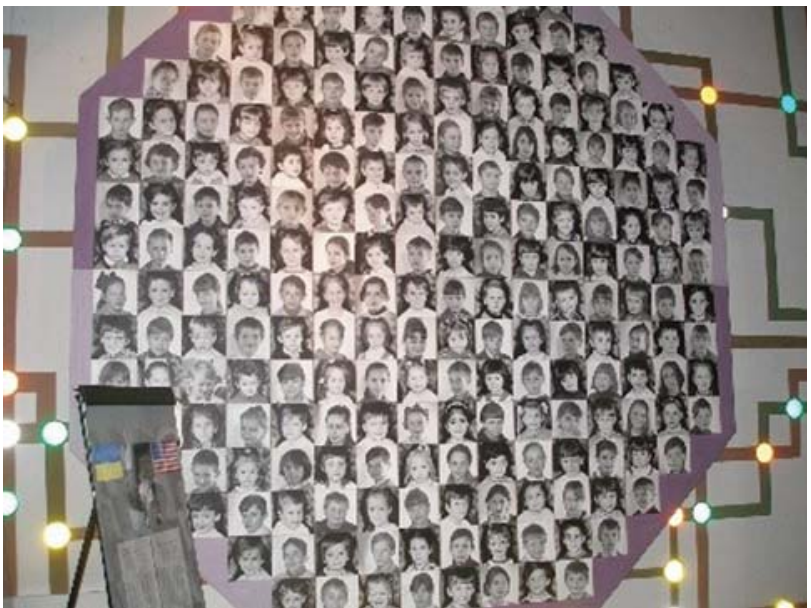

FIGURE 13. Chernobyl Museum, Kyiv, showing collage of children affected by the Chernobyl catastrophe (photo by Natalie Kopytko, 2007).

the impacts of the accident could not or would not be published under the strict Soviet regime. Two people died almost immediately, 28 more succumbed to acute radiation poisoning in the 3 months that followed. How many more suffered due to the spread of radioactive materials or because of their service to the fatherland in the zone? The true story will never be known, and proper methods for making such estimates remain highly contentious. Nevertheless, reasonable models estimate 40,000 fatal cancers in the entire world by 2065 , plus other health effects [34].

I continue to feel the power of that trip to Chernobyl and Ukraine. Shortly after returning, I changed the focus of my master's thesis from cultural responses to forests to an inquiry into the rationale for building new nuclear reactors in the United States. I broadened that research interest and wrote a $\mathrm{PhD}$ dissertation exploring the displacement of people that accompanies nuclear power projects. My three case studies included the Hanford Nuclear Reservation (WA, USA), a proposed six-reactor complex for Jaitapur (Maharashtra, India), and Chernobyl. In all cases, local people have paid the price for the impersonal, mechanistic, business-first approach taken to site selection, land acquisition, worker relocation, construction, commissioning or decommissioning, and the health impacts of nuclear projects. Local people lost their livelihoods, ties to communities they held dear, and family members as government officials pushed to erect concrete behemoths to harness the power of the atom.

\section{CONCLUSION}

Even though the events surrounding the Chernobyl catastrophe have tended to fade from memory (in the United States but not in Ukraine), and the interest in its contributions to the nuclear debate may seem dated, the lessons that can be learned from visits to this site remain relevant.

Field trips to all types of contemporary energy facilities should be a vital part of educational programs in environmental studies. Some others have noted that the use of field trips is declining, and we lament this. Others have pointed out the tendency for environmental studies to emphasize field trips about the natural environment compared to the built environment. We firmly believe that trips to explore issues in the latter are of co-equal importance for environmental students. Our experiences with the Chernobyl field trip increase our sense that field trips to the built environment should increase.

Climate change, a top environmental risk, affects both the built and unbuilt environments. It is a symptom of dependence on fossil fuels used for energy, and mitigation of climate change will require substituting other energy sources for coal, oil, and gas. Some have embraced renewed construction of nuclear power plants as mitigation for climate change, but the economics of nuclear power remain dismal [35]. In the future, field trips to energy sites in environmental studies are likely to find that installations using hydropower, wind, and solar power far more relevant, engaging, and powerful, but perhaps not quite as life-changing.

Such field trips can stimulate discussions about the pros and cons of various sources of energy, provide students with an up-close look at energy installations and firsthand experience with their enormity and their power (physical, electrical, and emotional), and motivate them to continue to ask critical questions and seek answers as they explore the interplay of humans and the earth.

\section{AUTHOR CONTRIBUTIONS}

The main text was prepared by Perkins, Kopytko, and Saul. Kopytko and Saul each prepared their respective individual statements with comments from each other and also from Perkins.

\section{ACKNOWLEDGMENT}

We are deeply indebted to Tetyana Murza. Without her full participation as a faculty member, this field trip would 
not have been possible. Andriy Martynyuk provided excellent advice on the structure of activities in Ukraine. The late Michael Mariotte provided excellent advice and support to both Murza and Perkins, and he supplied the financial support for Perkins to attend the Chornobyl +20 conference in Kyiv in 2006. We appreciate the professional inputs and friendly welcome of many Ukrainians still grappling with the effects of Chernobyl. We thank the very helpful comments received from the anonymous peer-reviewers.

\section{FUNDING}

No outside source of funding supported the preparation of this case study.

\section{COMPETING INTERESTS}

The authors have declared that no competing interests exist.

\section{REFERENCES}

I. Greene JP, Kisida B, Bowen DH. The educational value of field trips. Educ Next. 20 I 4: 78-86; Tal T, Steiner L. Patterns of teacher-museum staff relationships: school visits to the educational center of a science museum. Can Math Sci Technol. 2006; 6: $25-46$.

2. Alon NL, Tal T. Teachers as secondary players: involvement in field trips to natural environments. Res Sci Educ. 2017;47: 869-887; Pauw JB, Van Hoof J, Van Petegem P. Effective field trips in nature: the interplay between novelty and learning. J Biolog Educ. 2019;53(I): 2 I-33; Tal T, Alon NL, Morag O. Exemplary practices in field trips to natural environments. J Res Sci Teach. 20 I 4;5 I (4): 430-46 I.

3. Barton K. Exploring the benefits of field trips in a food geography course. J Geogr. 20 1 7; I 1 6(6): 237-249; Peterson RB. Taking it to the city: urban-placed pedagogies in Detroit and Roxbury.J Environ Stud Sci. 20 I 8;8: 326-342.

4. Short F, Lloyd T. Taking the student to the world: teaching sensitive issues using field trips. Psychol Teach Rev. 2017;23(1): 49-55.

5. Barton K. Exploring the benefits of field trips in a food geography course. J Geogr. 2017; I 16(6): 237-249; Forest K, Rayne S. Thinking outside the classroom: integrating field trips into a first-year undergraduate Chemistry curriculum. J Chem Educ. 2009;86(I I): I 290-I 294; Greene JP, Kisida B, Bowen DH. The educational value of field trips. Educ Next. 2014: 78-86.

6. Peterson RB, Taking it to the city: urban-placed pedagogies in Detroit and Roxbury. J Environ Stud Sci. 20 I 8;8: 326-342; Barton K. Exploring the benefits of field trips in a food geography course. J Geogr. 20 I 7; I I 6(6): 237-249; Larsen C, Walsh C, Almond N, Myers C. The "real value" of field trips in the early weeks of higher education: the student perspective. Educ Stud. 20 1 7;43 (I): I I O- I 2 I.
7. Perkins JH. Changing Energy: The Transition to a Sustainable Future. Oakland: University of California Press; 2017.p. 343.

8. Deutch JM, Moniz EJ. The nuclear option. Sci Am. 2006;295(3): 76-83.

9. Davis SJ, Nathan S, Lewis NS, Shaner M, et al. Net-zero emissions energy systems. Science. 2018;360: 1419. DOI: I 0. 1 I 26/science.aas9793

ı。. National Energy Policy Deployment Group. National Energy Policy. Washington: U.S. Government Printing Office; 2001 .

I . Grimes RW, Nuttall WJ. Generating the option of a twostage nuclear renaissance. Science. 20 10;329: 799-803.

I 2. Saul KM, Perkins JH. Nuclear power: is it worth the risks? In Byrne J, Wang Y-D, eds. Green energy economies: The search for clean and renewable energy. Energy Environ Policy. 2014 ; 10 : $276-295$.

13. U.S. Atomic Energy Commission. Civilian Nuclear Power: A Report to the President, 1962. Washington: U.S. Atomic Energy Commission; 1962. p. 76.

I4. Bupp IC, Derian J-C. Light Water: How the Nuclear Dream Dissolved. New York: Basic Books; i 978. p. 24 I.

I 5. Perkins JH. Development of risk assessment for nuclear power: insights from history. J Environ Stud Sci. 2014;4: $273-287$.

16. U.S. Department of Energy. Decision-Makers Forum on a Unified Strategy for Nuclear Power (INEEL/EXT-04-02506). Idaho National Laboratory; 2004. p. I 2.

17. U.S. Energy Information Administration. Annual Energy Review 2006. Washington: Energy Information Administration; 2007. p. 9. Table I.3, percent calculated by authors.

I 8. Abbott D. Limits to growth: can nuclear power supply the world's needs? Bull At Sci. 20 I 2;68(5): 23-32.

19. Shrader-Frechette K. What Will Work: Fighting Climate Change with Renewable Energy, Not Nuclear Power. New York: Oxford University Press; 20 I r. p. 368.

20. Tal T, Alon NL, Morag O. Exemplary practices in field trips to natural environments. J Res Sci Teach. 2014;5 I: $430-46 \mathrm{I}$.

21. Short F, Lloyd T. Taking the student to the world: teaching sensitive issues using field trips. Psychol Teach Rev. 2017;23: 49-55; Tal T, Alon NL, Morag O. Exemplary practices in field trips to natural environments. J Res Sci Teach. 201 4; 5 I: 430-46I.

22. Plokhy S. Chernobyl: The History of a Nuclear Catastrophe. New York: Basic Books; 20 r 8. p. 404.

23. United Nations Scientific Committee on the Effects of Atomic Radiation. Sources and Effects of Ionizing Radiation: UNSCEAR 2008 Report to the General Assembly with Scientific Annexes. Annex D. Health Effects Due to Radiation from the Chernobyl Accident. New York: United Nations; 20II.p. 2 I9.

24. The Chernobyl Gallery. New Safe Confinement. Available: http://www.chernobylgallery.com/chernobyl-disaste r/new-safe-confinement/. Accessed 3 September 2018. 
25. Short F, Lloyd T. Taking the student to the world: teaching sensitive issues using field trips. Psychol Teach Rev. 201 7;23: 49-55.

26. Cooper M. A dozen reasons for the economic failure of nuclear power. Bull At Sci. 2017. Available: https://thebullet in.org/201 7 / 1 o/a-dozen-reasons-for-the-economic-failure-of-n uclear-power/. Accessed 30 August 20 I 8.

27. Plumer B. Georgia, Facing 'Difficult Dilemma', Keeps Nuclear Project Alive. New York Times, 2 I Dec 20 r 7. Available: https://www.nytimes.com/20 I 7/ I 2/2 I/climate/georgia-vogtl e-nuclear.html. Accessed 30 August 20 I 8.

28. Hiltzik M. America's First '2 $\mathrm{I}^{\text {st }}$ Century Nuclear Plant' Already Has Been Shut Down for Repairs. Los Angeles Times, 8 May 2017. Available: http://www.latimes.com/business/ hiltzik/la-fi-hiltzik-nuclear-shutdown-20 I 70 508-story.html. 30 August 20 I 8.

29. Larsen C, Walsh C, Almond N, Myers C. The "real value" of field trips in the early weeks of higher education: the student perspective. Educ Stud. 20 I 7;43( I): I $10-$ I 2 I.

30. Kopytko N, Perkins JH. Climate change, nuclear power, and the adaptation-mitigation dilemma. Energy Policy. 20 I I 39: $318-333$.

3r. Kopytko N. Climate change could spell the end for nuclear power, not vice versa. The Guardian. 20I I. Available: https://www.theguardian.com/commentisfree/cif-green/20 I I / mar/ I 8/nuclear-power-climate-change-risks.
32. Kopytko N. The climate change threat to nuclear power. New Sci. 20 I I 2 8 I 3: 22-23.

33. Kopytko N. Uncertain seas, uncertain future for nuclear power. Bull At Sci. 201 5. Available: http://thebulletin.org/ $2015 / \mathrm{march} /$ uncertain-seas-uncertain-future-nuclearpower80680 I 5 . Accessed 3 March 2015.

34. Ian Fairlie I, Sumner D. The Other Report on Chernobyl: An Independent Scientific Evaluation of the Health-Related Effects of the Chernobyl Nuclear Disaster. Vienna: Weiner Umweltanhaltschaft; 2016. pp. 98-100. Available: www.cherno bylreport.org.

35. See, for example, Scoppe CR. I Year after SCE\&G and Santee Cooper Pulled the Plug at VC Summer: How We Got Here. The State. 3 I Jul 20 I 8. Available: https://www.thestate.c om/opinion/opn-columns-blogs/cindi-ross-scoppe/article 1765 39946.html. Accessed 9 August 2018; GreenTech Media. Georgia regulators vote to move forward with the Vogtle nuclear project. 2 I Dec 20 I 7. Available: https://www.greentech media.com/articles/read/georgia-regulators-vote-move-forwar d-with-vogtle-nuclear-project\#gs.WoMQMBQ. Accessed 9 August 20 18; Safer D, Barczak S. Watts Bar Unit 2, the last old reactor of the $20^{\text {th }}$ century: a cautionary tale. Bull At Sci. 2015. Available: https://thebulletin.org/20 I 5/ 1 //watts-bar-unit-2-la st-old-reactor-of-the-2oth-century-a-cautionary-tale/. Accessed I $\circ$ August 20 I 8. 